\title{
Scorpionism due to Tityus neoespartanus (Scorpiones, Buthidae) in Margarita Island, Northeastern Venezuela
}

\author{
Escorpionismo por Tityus neoespartanus (Scorpiones, Buthidae) \\ na Ilha de Margarita, Nordeste da Venezuela
}

\author{
Leonardo De Sousa ${ }^{1,2}$, Jenny Boadas ${ }^{2}$, Demetrio Kiriakos ${ }^{1,2}$, Adolfo Borges ${ }^{3,4}$, \\ Jesús Boadas², Jenny Marcano², Iván Turkali² and Miguel De Los Ríos ${ }^{2}$
}

\begin{abstract}
The first two cases of scorpion envenoming caused by Tityus neoespartanus (Buthidae) are described. The accidents took place within human environments (one inside a home and the other inside a school), in the village of La Sierra, Margarita Island, State of Nueva Esparta, Northeastern Venezuela. Both cases were moderately severe and developed pancreatic involvement and electrocardiographic abnormalities. This report allows inclusion of Margarita Island among the endemic areas of scorpionism in Venezuela.
\end{abstract}

Key-words: Scorpionism. Tityus neoespartanus. Margarita Island. Venezuela.

\section{RESUMO}

Descrevem se os dois primeiros casos de escorpionismo por Tityus neoespartanus (Scorpiones, Buthidae). Os acidentes ocorreram no ambiente antrópico (um no domicilio e outro na escola) na aldeia de La Sierra, Ilha de Margarita, Estado de Nueva Esparta, Nordeste da Venezuela. Os dois acidentes, moderadamente graves, cursaram com acometimento pancreático e alterações eletrocardiografias. Este reporte permite incluir à Ilha de Margarita entre as áreas endêmicas de escorpionismo na Venezuela.

Palavras-chaves: Escorpionismo. Tityus neoespartanus. Ilha de Margarita. Venezuela.

In Venezuela, envenoming by scorpions of medical importance is endemic to the main mountain ranges and constitutes a health problem, particularly in the densely populated northernmost section of the country ${ }^{2}{ }^{11}$. This area is the habitat of various species of the buthid genus Tityus, which are of considerable epidemiological and medical relevance since at least ten of them have been implicated in severe and fatal envenoming cases among children and young adults ${ }^{2311}$. In northeastern Venezuela, the areas with the greatest risk of scorpion envenoming are located within the Paria peninsula, and the Turimiquire and Bergantín massifs (including their piedmont areas), comprising the states of Anzoátegui, Monagas and Sucre P $^{9111213}$. Up until now, no records documenting the prevalence and severity of scorpion envenoming on the islands of northeastern Venezuela have been available, including Margarita Island, State of Nueva Esparta. A popular tourist destination, Margarita's population has increased considerably in recent years, with consequently higher risk of envenoming by local endemic fauna, including snakes (A. Rodríguez-Acosta: personal communication, 2007). In this study, we describe the first two cases of scorpionism ever reported from Margarita Island. The victims were children from the village of La Sierra (Arismendi municipality), on the border of Cerro El Copey National Park, 20km north of Porlamar, Margarita's main commercial center (Figure 1), who developed acute pancreatitis and electrocardiographic abnormalities. The taxonomic diagnosis confirmed that the species involved in both accidents was Tityus neoespartanus González-Sponga ${ }^{16}$.

\footnotetext{
1. Centro de Investigaciones en Ciencias de la Salud, Instituto de Investigación y Desarrollo Anzoátegui, Universidad de Oriente, Núcleo de Anzoátegui, Puerto La Cruz, Venezuela. 2. Escuela de Ciencias de la Salud, Universidad de Oriente, Núcleo de Anzoátegui, Puerto La Cruz, Venezuela. 3. Laboratorio de Toxinas Animales, Centro de Biociencias y Medicina Molecular, Instituto de Estudios Avanzados, Caracas, Venezuela. 4. Instituto de Medicina Experimental, Facultad de Medicina, Universidad Central de Venezuela, Caracas, Venezuela.

This work was partially supported by grant number CI-1-0403-0799/97-99 (to L.D.S.) from the Consejo de Investigación de la Universidad de Oriente .

Address to: Dr. Leonardo De Sousa. Centro de Investigaciones en Ciencias de la Salud, Instituto de Investigación y Desarrollo Anzoátegui, Universidad de Oriente, Núcleo de Anzoátegui, Puerto La Cruz 6023, Apartado Postal 4774, Anzoátegui, Venezuela.

Tel: 58281 418-2042, Fax: 58281 420-3219

e-mail: leonardodesousa@yahoo.com

Recebido para publicação em: 17/05/2007

Aceito em: 06/11/2007
} 


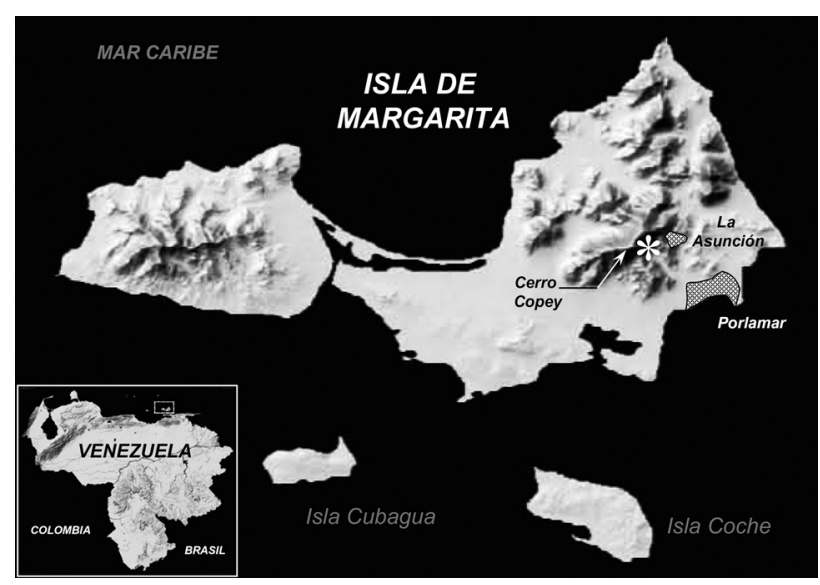

Figure 1 - Geographical location of Margarita Island (State of Nueva Esparta), northeastern region of Venezuela.

\section{CASE REPORTS}

Case 1. This was an eight-year-old boy whose home was on the main street of the village of La Sierra, Arismendi municipality, Margarita Island. He was stung by a scorpion on his right foot at 7:00am on June 26, 2000, while putting on a shoe in his bedroom. The child presented immediate, intense pain in the lower section of his right leg that prevented him from standing. He vomited four times, starting approximately 30 minutes after the accident. The vomit was bilious and was preceded by intense, colic-like pain in the right half of the abdomen. Sixty minutes after the accident, the boy was admitted to a class II
Salamanca urban clinic, presenting cold skin, bilious vomit and dyspnea. The scorpion responsible for the sting was brought along. While hospitalized, the patient developed generalized muscle tremors (particularly in the arms), abundant and thick sialorrhea, diaphoresis, mucocutaneous paleness, piloerection and bilateral myosis. Upon physical examination, there were signs of dehydration, tachypnea (respiratory rate $=26$ ), cardiac arrhythmia (heart rate $=90$ ) and irregular pulse. The patient's abdomen was painful, with deep palpation at the epigastrium and left hypochondrium. Laboratory analyses (in the Salamanca clinic) (Table 1) revealed abnormalities in the Schilling hemogram

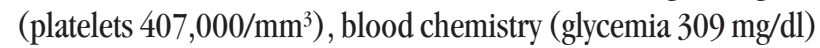
and serum amylase (353U/1) and lipase (359.6U/1) activity. A diagnosis of acute pancreatitis was proposed on the basis of the recorded signs and symptoms. The patient was hydrated using Ringer's lactate solution, and cimetidine and metoclopramide were administered intravenously. Because of the severity of the case and given the fact that the class II Salamanca clinic did not possess a stock of anti-scorpion antivenom, the patient was referred to Margarita's Dr. Luís Ortega Central Hospital, which is located in Porlamar. He was admitted at 11:00am The abovementioned diagnosis was confirmed upon admission to the Gastroenterology Service. The initial treatment was maintained and a nasogastric catheter was inserted. An absolute diet was prescribed, with hematological control and determination of plasma amylase, electrolytes and calcium levels. Ultrasound examination on June 26, 2000, revealed that the volumes of the liver, gallbladder, bile ducts and spleen were normal, without evidence of infiltration.

Table 1 - Laboratory test data. Case 1.

\begin{tabular}{|c|c|c|c|c|c|}
\hline \multirow[b]{2}{*}{ Test } & \multirow{2}{*}{$\begin{array}{c}\text { Salamanca } \\
\text { June } 26,2000 \\
\text { (am) }\end{array}$} & \multicolumn{4}{|c|}{ Dr. Luis Ortega Hospital, Porlamar } \\
\hline & & $\begin{array}{c}\text { June } 26,2000 \\
(\mathrm{pm})\end{array}$ & June 27,2000 & June 28,2000 & June 29,2000 \\
\hline Hemoglobin $(\mathrm{g} / \mathrm{dl})$ & 14 & 12.7 & 12.2 & 12.3 & \\
\hline Hematocrit (\%) & 44.8 & 39.6 & 37.5 & 38.1 & \\
\hline MCV & 89.7 & 85 & 85 & 86 & \\
\hline $\mathrm{MCH}$ & 29.1 & 27.2 & 27.8 & 27.6 & \\
\hline MCHC & 32.4 & 31.9 & 32.6 & 32.3 & \\
\hline Leukocytes $\left(\mathrm{mm}^{3}\right)$ & 5.000 & 15.600 & 23.700 & 13.600 & \\
\hline neutrophils (\%) & 65 & 90 & 88 & 84 & \\
\hline lymphocytes (\%) & 35 & 10 & 12 & 15 & \\
\hline eosinophils (\%) & & & & 1 & \\
\hline Platelets $\left(\mathrm{mm}^{3}\right)$ & 407.000 & 323.000 & 283.000 & 245.000 & \\
\hline Urea (mg/dl: 15-39) & 33 & & & 28.5 & \\
\hline Creatinine (mg/dl: 0.6-1.4) & 0.7 & & & 0.2 & \\
\hline PT (sec) & $11^{\prime \prime}\left(\mathrm{C}: 12^{\prime \prime}\right)$ & & & & \\
\hline PTT (sec) & $30^{\prime \prime}\left(\mathrm{C}: 30^{\prime \prime}\right)$ & & & & \\
\hline Glycemia (mg/dl: 70-110) & 309 & 209 & 132 & 126 & 85 \\
\hline Serum amylase (U/1: 20-112) & 353 & 370 & 186 & 83 & 45 \\
\hline Serum lipase (U/1: 50-140) & 359.6 & & & & 178 \\
\hline \multicolumn{6}{|l|}{ Electrolytes } \\
\hline $\mathrm{Ca}^{++}(\mathrm{mEq} / \mathrm{l})$ & & & 8.4 & & \\
\hline $\mathrm{Na}^{+}(\mathrm{mEq} / \mathrm{l})$ & & & 136.9 & & \\
\hline $\mathrm{Cl}^{-}(\mathrm{mEq} / \mathrm{l})$ & & & 104.4 & & \\
\hline $\mathrm{K}^{+}(\mathrm{mEq} / \mathrm{l})$ & & & 4.04 & & \\
\hline
\end{tabular}

am: ante meridium, pm: post meridium, MCV: mean corpuscular volume, MCH: mean corpuscular hemoglobin, MCHC: mean corpuscular hemoglobin concentration, PT: prothrombin time, PTT: partial thromboplastin time (normal values between parentheses). 
The pancreas was also shown to be of normal size but with an edematous pattern. From this, a final diagnosis of edematous pancreatitis was made. Laboratory tests demonstrated persistent leukocytosis, hyperglycemia and hyperamylasemia. On June 27, the cholinergic symptoms subsided but palpitations still persisted, and therefore an electrocardiogram was performed. This showed the presence of complete atrioventricular blockade of intermittent type was evidenced. On June 29, the glycemia and amylase levels became normal; only serum lipase activity remained high. The patient was discharged on that day and had spontaneous evolution, since no anti-scorpion antivenom was administered. One year later, an abdominal ultrasound scan demonstrated the existence of pancreatic microcalcifications.

Case 2. A 13-year-old male student was stung by a scorpion at 9:30am on May 10, 2006, in a classroom in La Sierra primary school, on the lateral face of his right thigh. He presented immediate, intense non-irradiating pain, which was exacerbated by leg movements. Diffuse, intense and colic-like abdominal pain also presented 15 minutes after the accident. Diaphoresis and sialorrhea were also recorded. The patient vomited three times, all with food content. He was taken to the Dr. Luis Ortega Hospital, and was admitted at 10:15am. The scorpion responsible was brought along. Upon physical examination, the patient demonstrated abundant and thick sialorrhea, vomiting (twice), diaphoresis, mucocutaneous paleness, piloerection and bilateral myosis. In addition, tachypnea (28 per min) and tachycardic and arrhythmic cardiac noises ( 120 beats per min; electrocardiogram showed premature supraventricular contractions). His abdomen was found to be painful on deep auscultation at the level of the epigastrium and left hypochondrium. The patient was hydrated using saline solution. Cimetidine and metoclopramide were administered intravenously. In addition, three ampoules (5ml each) of anti-scorpion antivenom (anti-Tityus discrepans; Biotecfar ${ }^{\circledR}$, School of Pharmacy, Universidad Central de Venezuela) were also given, diluted in $25 \mathrm{ml}$ of saline solution. Laboratory tests revealed leukocytosis $\left(17,500 / \mathrm{mm}^{3}\right)$, hyperglycemia $(250 \mathrm{mg} / \mathrm{dl})$ and hyperamylasemia $(438 \mathrm{mg} / \mathrm{dl})$. Abdominal ultrasound scans demonstrated edematous pancreatitis. The clinical and electrocardiographic manifestations disappeared two hours after antivenom administration; only paresthesia of the affected limb remained for three days after the accident. Glucose levels and amylase activity were restored to their normal values within 24 hours of antivenom application. The pancreas ultrasound pattern was also restored after that period.

The scorpion specimens involved in the accidents, which were brought to the clinic by the victims' relatives, were sent to the Health Science Center (CICS) of Universidad de Oriente (Anzoátegui Campus), Venezuela, and were deposited in the Scorpion Collection of the Toxinology Laboratory (CELT), where they were given the catalog numbers CELT 412 (Case 1) and CELT 1102 (Case 2). The taxonomical diagnosis allowed classification of both specimens as Tityus neoespartanus González-Sponga ${ }^{16}$ (Scorpiones, Buthidae). Morphometric data were recorded in $\mathrm{mm}$ using a Mitutoyo ${ }^{\circledR}$ calibrated digital caliper under an Olympus SZH10® stereoscopic microscope.
The morphometric data for CELT 421 (우) were: length of carapace 5.63; width of carapace 6.41; length of right chela 11.48; width of right chela 2.53; length of movable finger (right chela) 6.93 ; length of right tibia 6.42 ; length of right femur 5.53; length of mesosoma 18.80; metasomal segments: I (width/ length) $3.11 / 4.16$, II 2.93/5.34, III 2.99/5.98, IV 3.13/6.48 and $\mathrm{V}$ 3.20/6.96; length of telson 5.97; length of right pecten 3.78; total body length 54.32 ; number of pectineal teeth (right/left): 20/20; and number of oblique lines of denticles on the movable finger (right chela): 16.

The morphometric data for CELT 1102 ( $\left.\sigma^{7}\right)$ were: length of carapace 5.55; width of carapace 5.91; length of right chela 12.30; width of right chela 2.64; length of movable finger (right chela) 6.91 ; length of right tibia 7.18; length of right femur 6.54; mesosoma of length 18.98; metasomal segments: I (width/ length) $2.79 / 5.59$, II 2.66/7.22, III 2.58/7.92, IV 2.56/8.73 and $\mathrm{V} 2.74 / 8.82$; length of telson 7.38 ; length of right pecten 4.57 ; total body length 70.19 ; number of pectineal teeth (right/left): 20/21; and number of oblique lines of denticles on the movable finger (right chela): 16.

\section{DISCUSSION}

The Venezuelan scorpion fauna is highly diverse, including 184 species described up to $2006^{25}$. Among the scorpion taxa, the medically important genus Tityus contains 52 species that are distributed over the most densely populated areas, particularly in the northernmost section of the country ${ }^{2}{ }^{11}$. Margarita Island (among the islands in northeastern Venezuela) is known to be inhabited by only two buthid scorpions, Tityus neoespartanus ${ }^{16}$ and Rhopalurus laticauda. The latter species has the widest distribution range of all Venezuelan $\operatorname{tax}^{17}{ }^{18}$, but in fact it is the least venomous of all Venezuelan scorpions tested toxicologically to date ${ }^{11}$. Tityus neoespartanus inhabits the island's tropophilous humid forests. Its type locality is the Cerro El Copey National Park (Arismendi municipality), and its distribution range appears to be restricted to the highest areas of Margarita, around the villages of Las Piedras (Mariño municipality) and Fuentidueño (Díaz municipality $)^{16}$. In this study, Tityus neoespartanus is for the first time implicated as a species producing moderately severe cases of scorpionism in Margarita Island.

Over the entire region of the northeastern Venezuelan mainland and islands, only one accident, in the rural locality of El Toyano, Turimiquire subregion, State of Anzoátegui, had previously been documented clinically. That report, by De Sousa et al $l^{2}$, described the case of a nine-year-old boy who presented acute pulmonary edema, hematological abnormalities, upper digestive hemorrhage, and direct left hemiplegia, secondary to the scorpion envenoming. Several patients have been admitted to the Luis Razetti University Hospital from the same mountainous region, presenting cardiac arrhythmias characterized by bradycardia and atrioventricular blockade (D Kiriakos and L De Sousa: unpublished data). Scorpion collections carried out in El Toyano and surrounding areas demonstrated that only two sympatric species exist in the region: Tityus nororientalis ${ }^{16}$ and Tityus quirogae ${ }^{6}{ }^{10}$. 
Tityus neoespartanus, the species responsible for the envenoming pattern described here for the first time, is a species that is morphologically and genetically related to the mainland species Tityus nororientalis. In this regard, a recent molecular approach set up to study the phylogenetic associations between Venezuelan Tityus species has revealed that the scorpion population inhabiting the endemic area of Margarita does not differ significantly from populations of Tityus nororientalis, according to markers located in their mitochondrial DNA (A Borges: unpublished results). It remains to be determined whether the toxins produced by these two populations that act on voltage-gated ion channels and are capable of exerting noxious effects on envenomed humans differ in their activity and/or structure.

Children are the group at greatest risk regarding scorpion envenoming, from a clinical and epidemiological perspective $^{1114202122}$. The two cases documented in this report involved children who presented acute pancreatitis and cardiac electrical abnormalities. However, cases of adults stung by scorpions have also been reported in the State of Monagas, northeastern Venezuela. Some of these patients presented electrocardiographic abnormalities due to premature auricular and ventricular contractions, elevation of the ST segment, depression of the $\mathrm{J}$ point, prominent $\mathrm{U}$ wave, depression of the ST segment and sinus arrhythmia. This suggests the presence of premature repolarization syndrome and primary repolarization disorders of ischemic type ${ }^{11}$. For this geographical region (northeastern region of the State of Monagas), the species Tityus caripitensis $^{73}$ and Tityus quirogae $e^{6}$ have been implicated as responsible for the severe sting accidents recorded in that area.

The most lethal components of Tityus venoms are $\alpha$ and $\beta$-toxins that target the various isoforms of voltage-gated sodium channels ${ }^{3}{ }^{4}$. The systemic effects of these toxins are due, at least in part, to the discharge of catecholamine and acetylcholine as a result of the toxin-induced depolarization of pre and post-ganglionic terminals in the autonomous nervous system $^{311} 192026$. The toxin-mediated cholinergic discharge that takes place in the pancreas promotes premature activation of the enzymes produced within the acinar cell. These enzyme precursors, together with inflammatory mediators, are released from the damaged pancreatic tissue and are capable of altering the function of several distant tissues including the lungs. This pathological cascade can lead to the death of the envenomed victim due to respiratory distress ${ }^{13527}$.

Some reports have indicated that scorpions are capable of colonizing areas altered by human activities, thus suggesting that they have a strong preference for human habitats ${ }^{6101415}$, as in the accidents described here, including homes or schools. The high frequency of scorpion envenoming among children under six years of age in the northern coastal region of Venezuela suggests that the local scorpion fauna of medical importance behaves similarly 31124

This study makes it possible to include Margarita Island on the lethality map of the Venezuelan scorpion fauna originally proposed by Borges ${ }^{2}$ and more recently by Borges and De Sousa ${ }^{3}$. In their studies, they suggested a division of the country into Toxinological
Provinces, through the incorporation epidemiological, clinical, molecular and immunological data in order to gain more thorough comprehension of scorpion envenoming in this country.

\section{ACKNOWLEDGEMENTS}

Thanks are conveyed to Dr. Jesús Manzanilla (Museum of the Agricultural Zoology Institute, Universidad Central de Venezuela, Maracay) for his critically reading of the manuscript and appropriate suggestions.

\section{REFERENCES}

1. Bhatia M, Wong FL, Cao Y, Lau HY, Huang J, Puneet P, Chevali L. Pathophysiology of acute pancreatitis. Pancreatology 5: 132-144, 2005.

2. Borges A. Escorpionismo en Venezuela. Acta Biológica Venezuélica 16: 65-75, 1996

3. Borges A, De Sousa L. Escorpionismo en Venezuela: una aproximación molecular, inmunológica y epidemiológica para su estudio. Revista Facultad de Farmacia (Caracas) 69: 15-27, 2006

4. Borges A, García C, Lugo E, Alfonso M, Jowers M, Op den Camp H. Diversity of long-chain in Tityus zulianus and Tityus discrepans (Scorpiones, Buthidae): molecular, immunological, and mass spectral analyses. Comparative Biochemistry and Physiology Part C 142: 240-252, 2006.

5. Borges A, Trejo E, Vargas AM, Hernández A, Céspedes G, Alfonzo M. Pancreatic toxicity in mice elicited by Tityus discrepans and Tityus zulianus scorpion venoms. Investigación Clínica 45: 269-274, 2004.

6. De Sousa L. Especie nueva de Tityus (Scorpiones, Buthidae) de la Serranía del Turimiquire, Nororiente de Venezuela. Caracterización morfológica, geográfica y toxinológica. Tesis de Ascenso a Profesor Asociado, Universidad de Oriente, Barcelona, Anzoátegui, 2006.

7. De Sousa L, Bonoli S, Parrilla-Alvarez P, Ledezma E, Jorquera A, Quiroga M. The proposal of a new endemic macroregion for scorpionism in Venezuela. Journal of Venomous Animals and Toxins 5: 111, 1999.

8. De Sousa L, Bonoli S, Quiroga M, Parrilla-Alvarez P. Scorpion sting epidemiology in Montes Municipality of the State of Sucre, Venezuela: Geographic distribution. Revista do Instituto de Medicina Tropical de São Paulo 38: 147-152, 1996.

9. De Sousa L, Kiriakos D, Jiménez J, Michieli D, Rodríguez C, Mirabal J, Quiroga M. Accidente cerebrovascular isquémico por emponzoñamiento escorpiónico: Observación clínica. Saber 7: 7-14, 1995

10. De Sousa L, Manzanilla J, Parrilla-Álvarez P. Nueva especie de Tityus (Scorpiones: Buthidae) del Turimiquire, Venezuela. Revista de Biología Tropical (International Journal of Tropical Biology and Conservation) 54: 489-504, 2006.

11. De Sousa L, Parrilla-Alvarez P, Quiroga M. An epidemiological review of scorpion stings in Venezuela. The northeastern region. Journal of Venomous Animals and Toxins 6: 127-165, 2000.

12. De Sousa L, Parrilla-Alvarez P, Tillero L, Valdiviezo A, Ledezma E, Jorquera A, Quiroga M. Scorpion poisoning in the Acosta and Caripe Counties of Monagas State, Venezuela. Part 1: Characterization of some epidemiological aspects. Cadernos de Saúde Pública 13: 45-51, 1997.

13. De Sousa L, Vásquez D, Salazar D, Valecillos R, Vásquez D, Rojas M, ParrillaÁlvarez P, Quiroga M. Mortalidad en humanos por envenenamientos causados por invertebrados y vertebrados en el estado Monagas. Investigación Clínica 46: 241-254, 2005.

14. Gómez JP, Otero R, Núñez V, Saldarriaga M, Díaz A, Velásquez M. Aspectos toxinológicos, clínicos y epidemiológicos del envenenamiento producido por el escorpión Tityus fuhrmanni Kraepelin. Medunab 5: 159-165, 2002.

15. Gómez JP, Velásquez P, Saldarriaga M, Díaz A, Otero R. Aspectos biológicos y ecológicos del escorpión Tityus fuhrmanni (Kraepelin, 1914), en poblaciones del cerro El Volador y barrios aledaños de la ciudad de Medellín. Actualidades Biológicas 24: 103-111, 2002. 
16. González-Sponga MA. Arácnidos de Venezuela: Seis nuevas especies del género Tityus y redescripción de Tityus pococki Hirts, 1907, Tityus rugosus (Schenkel, 1932) n. comb. y Tityus nematochirus Mello-Leitão, 1940 (Scorpionida: Buthidae). Acta Biológica Venezuélica 16: 1-38, 1996.

17. González-Sponga MA. Guía para identificar escorpiones de Venezuela. Cuadernos Lagoven, Caracas, 1996.

18. Manzanilla J, De Sousa L. Ecología y distribución de Rhopalurus laticauda Thorell, 1876 (Scorpiones: Buthidae) en Venezuela. Saber 15: 3-14, 2003.

19. Mazzei-Dávila CA, Dávila DF, Donis J, Arata-Bellabarba G, Villarreal V, Barboza L. Sympathetic nervous system activation, antivenin administration and cardiovascular manifestations of scorpion envenomation. Toxicon 40: 1339-1346, 2002.

20. Mazzei-Dávila CA, Parra M, Fuenmayor A, Salgar N, González Z, Dávila DF. Scorpion envenomation in Mérida, Venezuela. Toxicon 35: 1459-1462, 1997.

21. Otero R, Navio E, Céspedes FA, Núñez MJ, Lozano L, Moscoso ER, Matallana C, Arsuza NB, García J, Fernández D, Rodas JH, Rodríguez OJ, Zuleta JE, Gómez JP, Saldarriaga M, Quintana JC, Núñez V, Cárdenas S, Barona J, Valderrama R, Paz N, Díaz A, Rodríguez O L, Martínez MD, Maturana R, Beltrán LE, Mesa MB, Paniagua J, Flórez E, Lourenço WR. Scorpion envenoming in two regions of
Colombia: clinical, epidemiological and therapeutic aspects. Transactions of the Royal Society of Tropical Medicine and Hygiene 98: 742-750, 2004.

22. Otero R, Uribe FL, Sierra A. Envenenamiento escorpiónico en niños. Actualizaciones Pediátricas 8: 88-92, 1998.

23. Quiroga M, Parrilla-Álvarez P, De Sousa L. The biology of Buthidae scorpions of the genus Tityus, a major cause of envenoming in northeastern Venezuela. Journal of Venomous Animals and Toxins 5: 104, 1999.

24. Reyes-Lugo M, Rodríguez-Acosta A. Scorpion envenoming by Tityus discrepans Pocock, 1897 in the northern coastal region of Venezuela. Revista Científica FCV-LUZ 11: 412-417, 2001.

25. Rojas-Runjaic FJ, De Sousa L. Catálogo de los escorpiones de Venezuela (Arachnida: Scorpiones). Boletín de la Sociedad Entomológica Aragonesa 40: 281-307, 2007.

26. Saldarriaga MM, Otero R. Los escorpiones: aspectos ecológicos, biológicos y toxinológicos. Medunab 3: 17-23, 2000.

27. Voronov E, Apte RN, Sofer S. The systemic inflamatory response syndrome related to the release of cytokines following severe envenomation. Journal of Venomous Animals and Toxins 5: 5-3, 1999. 